University of Nebraska - Lincoln

DigitalCommons@University of Nebraska - Lincoln

Faculty Publications: Department of Teaching, Department of Teaching, Learning and Teacher Learning and Teacher Education

Education

$1-2016$

\title{
Three Reading-Intervention Teachers' Identity Positioning and Practices to Motivate and Engage Emergent Bilinguals in an Urban Middle School
}

Jung-In Kim

University of Colorado Denver, jung-in.kim@ucdenver.edu

Kara Mitchell Viesca

University of Nebraska-Lincoln, kara.viesca@unl.edu

Follow this and additional works at: https://digitalcommons.unl.edu/teachlearnfacpub

Part of the Curriculum and Social Inquiry Commons, Disability and Equity in Education Commons, Educational Methods Commons, Junior High, Intermediate, Middle School Education and Teaching

Commons, and the Special Education and Teaching Commons

Kim, Jung-In and Viesca, Kara Mitchell, "Three Reading-Intervention Teachers' Identity Positioning and Practices to Motivate and Engage Emergent Bilinguals in an Urban Middle School" (2016). Faculty Publications: Department of Teaching, Learning and Teacher Education. 209.

https://digitalcommons.unl.edu/teachlearnfacpub/209

This Article is brought to you for free and open access by the Department of Teaching, Learning and Teacher Education at DigitalCommons@University of Nebraska - Lincoln. It has been accepted for inclusion in Faculty Publications: Department of Teaching, Learning and Teacher Education by an authorized administrator of DigitalCommons@University of Nebraska - Lincoln. 


\title{
Three reading-intervention teachers' identity positioning and practices to motivate and engage emergent bilinguals in an urban middle school
}

\author{
Jung-In Kim and Kara Mitchell Viesca
}

University of Colorado Denver

Corresponding author - Jung-In Kim, Program of Education and Human Development, School of Education and Human Development, University of Colorado Denver, Campus Box 106, P.O. Box 173364, Denver, CO 80217, USA; email jung-in.kim@ucdenver.edu

\section{Highlights}

- Teachers' motivational practices related to their positioning of emergent bilinguals.

- Teachers' historical and current resources partly supported their different positioning.

- Teachers need to reflect critically on positioning processes in the classroom.

- A holistic approach is needed in teacher education as situated in sociocultural contexts.

\begin{abstract}
This study investigated three urban middle-school teachers' practices with respect to motivating and engaging emergent bilinguals in reading-intervention classrooms by exploring the teachers' identity positioning. The three teachers' sociocultural and sociopolitical positioning of their students (e.g., students as individuals, as monolithic learners, or as problems) was found to be related to their practices for motivating and engaging the students (e.g., hybrid, calibrated, or imposed practices). The teachers' historical and current resources partially shaped how they positioned their students. The findings support that teachers should not only learn motivational practices but also reflect critically on positioning processes in the classroom.
\end{abstract}

Keywords: Urban middle-school teachers, Identity positioning, Critical theory, Emergent bilinguals, Motivational practices, Readingintervention classroom

\section{Introduction}

In the United States, an increase in immigrant students who are emergent bilinguals ${ }^{1}$ has led to a situation in which mainstream teachers have an insufficient understanding of how to best interact with and engage emergent bilinguals (Harper \& de Jong, 2009). According to Yoon (2008), most of the research regarding teachers' practices for emergent bilinguals has focused on practices supporting their linguistic needs. For instance, several prominent frameworks suggesting what teachers should know and be able to do focus on language, such as Linguistically Responsive Teaching (Lucas \& Villegas, 2011), Pedagogical Language Knowledge (Bunch, 2013) and Disciplinary Linguistic Knowledge (Turkan, de Oliveira, Lee \& Phelps, 2014). Clearly, for teachers of emergent bilingual learners, language and language development is important. However, currently there exists relatively limited number of studies

1 We use the term emergent bilinguals to signify our conceptual alignment with the languaging/translanguaging literature (i.e. García, 2009; García \& Wei, 2014) where language is viewed as a social process. From this perspective, bilingualism is responsive to various communicative needs that exist across the lifetime of a learner, thus positioning their bilingualism as responsive, flexible and dynamic and all bilinguals as emergent bilinguals. We further use this term to avoid the positioning of students as "other" or in accord with the monolingual bias towards English that exists in contemporary U.S. public schooling. We prefer to label students as what they are (emerging bilinguals) rather than in relationship to a deficit perspective of their ability to use English or in relationship to dominant groups in society. 
that have examined the complicated picture of emergent bilinguals' classroom motivational and engagement experiences. More research is needed to better understand and support teachers' interactions with emergent bilinguals that aim to motivate and engage students in regular education classrooms.

From the perspectives of achievement motivation as well as critical theory, the current study investigates how three White reading-intervention teachers approached motivating and engaging emergent bilinguals in their classrooms in an urban middle school. Furthermore, this study examined the teachers' practices particularly as related to their identity positioning (Harre \& van Langenhove,1999) of both their students and themselves as teachers in its social, cultural, and political context of the language and literacy classroom (e.g., Kumaravadivelu, 2012; Mitchell, 2013). We particularly paid attention to how sensitive these reading-intervention teachers are to bilingualism and the varying linguistic and cultural repertoire's of emergent bilinguals. Few studies have examined reading-intervention teachers' perspectives on the intervention process (Wilcox, Murakami-Ramalho, \& Urick, 2013), although teacher practices are filtered by teacher's identity positioning in the classroom context (e.g., Nolen, Ward, \& Horn, 2014; Yoon, 2008). Ultimately, particularly shedding light on the social, cultural, and political nature of teaching practices, this research aim to offer teachers insight into the practices to use in working with and engaging emergent bilinguals, and how teacher educators could help during the process (e.g., Olsen, 2008). Below, we begin by discussing (a) limited examinations of teachers' practices to motivate and engage emergent bilinguals, (b) the importance of understanding the teachers' practices with respect to their identity positioning, and (c) the importance of the investigation in the context of reading-intervention classes.

\subsection{Limited examinations of teachers' practices to motivate emergent bilinguals}

The field of achievement motivation has extensively investigated teachers' adaptive motivational practices, which help students experience willingness to learn, develop resilience, maintain positive affect, and participate in deeper cognitive and behavioral engagement (Pintrich \& Schunk, 2002). For example, as one of the major guiding theories of achievement motivation, Self- Determination Theory (SDT) has emphasized teachers' support of students' basic psychological needs for autonomy, relatedness, and competence to foster the students' intrinsic motivation or autonomous forms of motivation (Deci \& Ryan, 2002). Similarly, Assor, Kaplan, and Roth (2002) argued that teachers can foster students' autonomous motivation by "helping students experience the learning process as relevant to and supportive of their self-determined interests, goals, and values" (p. 264), instead of imposing teachers' ideas (i.e., controlling method; Reeve, 2009). Findings from other guiding theories (Dweck, 200o; Yeager \& Dweck, 2012) emphasized the importance of teachers' encouraging their students to build an incremental perspective on intelligence versus an entity orientation of intelligence, so that students can develop the belief that their intelligence is malleable and can grow. Yeager and Dweck (2012) argued the importance of psychological interventions that help support changing students' mindsets and what teachers can do to foster these mindsets and develop students' resilience in educational settings. Recently, teachers' adoption of these adaptive motivational practices has been reported to vary according to their beliefs (e.g., their efficacy in teaching or belief of their students' ability), even after they participated in professional development (PD) meetings through which they were provided with rationales and strategies to foster student motivation (Turner, Warzon, \& Christensen, 2011).
These studies have contributed to the rich body of research that examines what types of practices would allow teachers to support students' adaptive motivation: however, few studies have examined how teachers should motivate and engage the growing population of emergent bilinguals in general education classrooms. According to Yoon (2008) and Harper and de Jong (2009), teaching emergent bilinguals is not a mere matter of "just good teaching" or "studentcentered teaching," and thus ways to support and motivate the students need be examined in the social, cultural, and historical contexts that confront both the students and their teachers. Relatively limited research has started to examine the complicated picture of general education classroom practices, such as how to best support and engage emergent bilinguals, and limited attention has paid to what constitutes the teachers' adoption of practices to support and motivate the students addressing the students' "cultural and social needs" (Yoon, 2008, p. 504). The field of achievement motivation has increasingly supported the need to make a more situational examination of student motivation and teacher practices (e.g., Kaplan, Katz, \& Flum, 2012, ch. 7; Nolen et al., 2014; Turner et al., 2011; Urdan, 2014). This study particularly examined teacher motivational practices with regard to identity positioning of the teachers, which has received increasing attention.

\subsection{The importance of teachers' positioning in understand- ing their practices}

To shed light on the complex social and cultural aspects of classroom practices, researchers have increasingly emphasized the need to investigate the fluid, dynamic, and multifaceted identities or positions of both teachers and their students, as "subjectivities ... the multiple, fluid, and unstable relationships that make up a person" (Rogers, 2004, p. 276). Examinations of teachers' claimed, negotiated, or resisted identities and positioning have been particularly fruitful for understanding their complex instructional approaches to emergent bilinguals. For example, Yoon (2008) investigated three White teachers' pedagogical approaches through their positioning in relation to emergent bilinguals, grounded by positioning theory (Harre \& van Langenhove, 1999). Harre and Moghaddam (2003) posited that an identity position is "a loose set of rights and duties that limit the possibilities of action" (p. 5) and that positioning people in particular ways would afford or constrain various forms of thoughts and behaviors, including what they can say and do (Harre \& van Langenhove, 1999). Identity positioning is often claimed or negotiated by agents and is attributed by others during social relationships, and Harre and van Langenhove (1999) proposed different modes of positioning. Reflexive positioning involves one's intentional or unintentional engagement in self-positioning to unfold personal stories, whereas interactive positioning involves how one person's speech positions the other person during an interaction.

Yoon (2008) found that the White teachers displayed different pedagogical approaches (e.g., allowing or limiting emergent bilinguals' cultural or linguistic experiences; supporting or ignoring their social and cultural needs), which eventually shaped emergent bilinguals' differing participation and feelings of empowerment. The teachers' differing pedagogical approaches were shaped by their own different identity positioning, such as being a teacher for all students, for regular-education students, or of a single subject. Findings by Yoon (2008) highlighted that there is diverse teacher positioning in relation to emergent bilinguals, and this positioning is important in shaping teachers' classroom practices. Similarly, Reeves (2009) examined a secondary White English teacher's undifferentiated instruction and assimilative approach toward emergent bilinguals as related to his identity positioning. Reeves 
found that the teacher not only developed his own positioning but also made an intentional investment in positioning emergent bilinguals as "just like any [other] kid" (p. 38). Reeves (2009) found the teacher's positioning as problematic, which could be shaped through his lack of understanding of language development processes and bilingualism and through disadvantageously situating immigrant students in a political context.

Importantly, Mitchell (2013) addressed the political and sociocultural context of emergent bilingual student learning in secondary schools through a comprehensive review of the research literature. Through a critical race theory lens, she sought to identify the majoritarian stories (Love, 2004), or the dominant cultural narratives utilized to perpetuate racial oppression. Mitchell identified four prevalent stories that appeared across the research and impacted the schooling of emergent bilinguals in secondary schools: there is no story about race, difference is deficit, meritocracy is appropriate, and English is ALL that matters. Mitchell (2013) particularly supported the argument that "closer examination of the positioning of multilingual learners in policy and practice is necessary to substantially challenge these deficit perspectives and reposition secondary multilingual learners in terms of their assets rather than English language deficit" (pp. 340-341). In terms of identity, motivation and engagement, it appears that these stories are worth accounting for and disrupting in the education of emergent bilinguals.

\subsection{The context of this study: reading-intervention classes}

This study examines three reading-intervention teachers' practices with respect to motivating emergent bilinguals in an urban middle school. Approximately $22 \%$ of the nation's eighth-grade students, which might include emergent bilinguals, are not reading at or above the basic eighth-grade level (National Assessment of Educational Progress, 2013), and these students with reading difficulties would benefit from reading interventions (Edmonds et al., 2009). Reading interventions often consist of multiple tiers of intervention, including enhanced classroom-level instruction, supplemental intervention, and high-intensity intervention with special education (e.g., Denton, Fletcher, Anthony, \& Francis, 2006), addressing areas of decoding, fluency, vocabulary, and comprehension. Teachers' use of motivational practices, such as choosing texts to read, establishing goals for reading, has also been reported to increase students' motivation and engagement in reading tasks (Kamil et al., 2008).

However, how sensitive these interventions are to bilingualism and to the varying linguistic repertoires or cultural backgrounds of emergent bilinguals is not always clear. An increasing number of scholars have raised the concern that students often experience reductive literacy instruction. For example, Moore and Klingner (2014) synthesized reading intervention research studies that were designed and implemented for struggling students, and they asked more researchers to take into consideration the diverse needs of emerging bilinguals. Gutiérrez, Morales, and Martinez (2009) also argued against the narrow perspectives of student literacy learning and ability, which are linked to narrowly measured linguistic and literacy competence, and which thus hinder an appreciation of students' linguistic toolkits and cultural knowledge. Furthermore, an increasing number of studies have adopted critical perspectives and supported teachers' critical literacy practices (e.g., Rodriguez, 2011; Rogers, 2014). Critical literacy aims to "help children (and teachers) develop a sense of agency with literacy so that they can accomplish goals they deem important and also resist the coercive effects of literacy and language" (Rogers, 2014, p. 248) by "being sensitive to issues of power, justice, and equity" (p. 242).

The reading intervention classes have been reported to be taught by teachers with diverse teaching backgrounds, including teachers certified in elementary/secondary education, special education, English as a second language, and reading specialists (e.g., Denton et al., 2006). According to Wilcox et al. (2013), however, few studies have examined reading-intervention teachers' perspectives on the intervention process, although the intervention implementation is strongly dependent on teachers' preparation and practices. In light of the fact that teacher practices are filtered by teacher identities in the classroom context (e.g., Yoon, 2008), it is important to examine teachers' perspectives on the language and literacy classroom in its social, cultural, and political context (e.g., Mitchell, 2013). Furthermore, the complexity underlying teachers' adoption of motivational practices for emergent bilinguals should be the subject of a more sociocultural and situational examination (e.g., Urdan, 2014), considering that teachers' adoption of adaptive motivational practices is not facilitated merely through the provision of motivational strategies (e.g., Turner et al., 2011). Ultimately, an investigation of the dynamics of how mainstream teachers help emergent bilinguals engage in reading-intervention classrooms would help increase teachers' awareness of how their identity positioning and practices support or constrain emerging bilinguals' learning to read.

The present study examined the perspectives of three readingintervention teachers with regard to what types of practices they were using to motivate and engage emergent bilinguals and what constituted their use of specific motivational practices, with respect to their positioning of their students as learners as well as their positioning of themselves as teachers. We examined teachers' practices to motivate and engage students through motivational theories (e.g., SDT, Deci \& Ryan, 2002; the implicit theory of intelligence, Dweck, 200o) as well as critical perspectives examining the social, cultural, and political contexts of literacy and language practices (e.g., Mitchell, 2013). In addition, the reading-intervention teachers' positioning was examined adopting positioning theory (Harre \& van Langenhove, 1999). The following research questions guided the investigation: (1) How did the three White teachers position themselves and their students in their social, cultural, and political contexts of reading-intervention classes? (2) What major practices did the teachers use to motivate and engage emergent bilinguals in reading-intervention classes in an urban middle school, and how did the teachers' positioning relate to their major practices? Finally, (3) what are the implications for the teachers in motivating and engaging emergent bilinguals?

\section{Method}

\subsection{Setting}

The data were collected during a collaboration between an urban middle school and a university in the Midwestern U.S. over a period of approximately one academic year. A large majority of the students at the middle school was Latino/a (more than 9o\%), and slightly fewer than $90 \%$ of the students spoke Spanish as emergent bilinguals. Slightly more than $80 \%$ of the students were labeled "ELL," and more than $90 \%$ of the students qualified for free/ reduced lunch.

\subsubsection{Reading-intervention program}

During the participating academic year, all of the middleschool students were attending daily reading-intervention classes. The assistant principal of the middle school stated that the reading-intervention program was established approximately four years earlier because the middle school felt a sense of urgency upon learning that many students were reading below grade level. The levels of the reading-intervention classes ranged from 
"unsatisfactory" to "partially proficient" to "proficient" in accordance with the state's assessment of reading proficiency.

Among six reading-intervention teachers providing instruction for the middle-school students, two were teaching the unsatisfactory level, three were teaching the partially proficient level, and one was teaching the proficient level. One of the six teachers was a reading-intervention instructional coach. Fluency (using a curriculum-based measure) and vocabulary programs were required for students at the unsatisfactory or partially proficient level. In general, however, the teachers did not have a set curriculum because curriculum decisions and the various skills addressed in each class were determined based on the students' assessment data. After the baseline assessments of students at the beginning of the semester, quarterly progress monitoring assessments were conducted to lead the teachers' data-driven dialogues. The teachers frequently participated in various PDs that were mediated by the reading-intervention instructional coach.

\subsubsection{Collaboration between the school and the university}

Both the teachers and the administrators perceived middleschool students as "less motivated and engaged" than those in an associated high school. They also felt the middle-school students had substantially more "behavioral issues." As part of the collaboration between the school and university, PD sessions were conducted to help the six reading-intervention teachers learn motivational principles to aid in engaging middle-school students in classes. PD sessions occurred once a month during the academic year, eight times overall. Two instructors from the university, including a senior instructor and the first author of this paper, facilitated each session, which lasted approximately $75 \mathrm{~min}$. Motivating principles were based on Quate and McDermott (2009), our reading material, which included topics such as providing choices (i.e., autonomy-supportive practices), fostering caring relationships and encouraging collaborative learning environments (i.e., supporting students' relatedness needs), and offering appropriate levels of challenge and celebrating students' accomplishments (i.e., supporting students' competence). In addition, culturally relevant pedagogy based on the standards for effective pedagogy by the Center for Research on Education, Diversity \& Excellence (CREDE; Tharp, Estrada, Stoll Dalton, \& Yamauchi, 200o) was introduced to and discussed with the teachers, particularly connecting the standards with the various motivating practices and principles included. The teachers were typically asked to read a short article regarding the monthly topic ahead of time, to reflect on their practices, and to share ideas during the session. The instructional coach, one of the six teachers, and the two PD facilitators met both before and after each session for planning and debriefing.

It is important to note that unlike previous studies such as Turner et al. (2011), which investigated teachers' changes in beliefs by carefully focusing on their participation in PD, this study considered PD one of the sources or contexts in which teachers' motivational approaches were shaped. Therefore, the discourses discussed during the PD sessions or the impacts of the PD sessions as an intervention on the teachers' practices were not the main focus of this study. Additionally, the PD itself was not particularly critical (e.g., Mitchell, 2013). Conducting this study and the subsequent results actually suggest a need for more targeted critical approaches, which will be discussed in further detail below.

\subsection{Study participants}

The purpose of the study (i.e., to investigate the motivational practices of reading-intervention teachers) was explained first to the school principals and the reading-intervention instructional coach and then to the reading-intervention teachers during the first PD session. During the introduction of the study, the first author positioned herself as a co-facilitator, "foreigner/outsider" who was not a reading-intervention teacher, and "observer" who aimed to learn about the teachers' current use of motivational practices. Of the six teachers who belonged to the reading-intervention department and participated in the PD during the academic year, four teachers, all White, volunteered to participate in this study. The current paper presents only three teachers' results because of incomplete data for the one remaining teacher. Please see Table $\mathrm{i}$ for demographic information.

The three teachers had differing previous teaching experiences, previous educational experiences, and current roles that served as resources, which eventually shaped the teachers' positioning of their students.

In her first semester at the current middle school, Ms. Daniel (White, mid 20s) had three years of teaching experience at other urban high schools, in which the student populations were very similar to what she was teaching at the current middle school. In her first years of teaching at the high schools, she felt frustrated not understanding her students' lack of engagement ("Why doesn't everybody want to get an A? I don't understand. I gave you the worksheet. I am your teacher."). Ms. Daniel, however, eventually learned about the context of urban education while interacting with the students, as well as pursuing a master's degree in language and literacy education and serving as a graduate literacy coordinator at the K-8 level. Given her teaching and educational background, Ms. Daniel's role at the current middle school was to serve as "an ELD [English language development] teacher, [a] Spanish resource [teacher]" with the aim of developing the English language abilities of the Spanish-speaking students.

Ms. Austin (White, late 2os), in her second year at the current middle school, had six to seven years of experience teaching reading in elementary and middle schools and earned a master's degree in educational policy. In her reading-intervention class during her first year at the current middle school, however, Ms. Austin reported that she had a very difficult time engaging her students ("I have NEVER had [the classroom cultural issues with students] before in all of my years of teaching ... I was so concerned about motivating the kids last year ... They were complacent and did not want to persevere"). Hired as an instructional coach and teacher for the reading-intervention classes, Ms. Austin was in charge of improving students' reading proficiency by leading the development of a joint curriculum based on student high-stakes reading assessment data, facilitating department meetings and PDs, and coaching the other reading-intervention teachers. In accordance with her role at the school, she had familiarity with the assessment data by attending a few workshops organized by the school.

Mr. Walker (White, early 20s) was beginning his first year at the middle school after completing the "Teach for America" program. He considered himself "a new teacher" and "a novice" because of his lack of teaching experience. He had majored in social science and foreign language. He only had limited teaching experience to draw upon and felt uncertain at times.

\subsection{Data sources}

Three main data-collection methods were utilized to document the teachers' positioning and motivational practices in one of their classes, which served as the target classroom. Direct observations of 50 -min classes $(50 \mathrm{~min} \times 4$ times during the academic year $\times 3$ teachers) were supplemented by audio taping each teacher's instruction. Direct observations were conducted two times per semester, one during the early-to mid-semester and the other at the end of the semester (i.e., September, December, February, and April). The teachers were not provided with the specific dates and 
Table 1. Demographics of the three reading-intervention teachers.

\begin{tabular}{|c|c|c|c|}
\hline Name & Ms. Daniel & Ms. Austin & Mr. Walker \\
\hline Sex & Female & Female & Male \\
\hline Age & Mid 20 s & Late $20 \mathrm{~s}$ & Early 20 s \\
\hline Race & White & White & White \\
\hline $\begin{array}{l}\text { Previous } \\
\text { teaching } \\
\text { experiences }\end{array}$ & $\begin{array}{l}\text { Three years of teaching experience at } \\
\text { other urban high schools with similar } \\
\text { student populations }\end{array}$ & $\begin{array}{l}\text { Six to seven years of teaching experience } \\
\text { at other elementary and middle schools, } \\
\text { and } 1 \text { year at the current middle school }\end{array}$ & None \\
\hline $\begin{array}{l}\text { Previous } \\
\text { educational } \\
\text { experiences }\end{array}$ & $\begin{array}{l}\text { Master's degree in language and literacy } \\
\text { education (with 1-2 years as a graduate } \\
\text { literacy coordinator at the K- } 8 \text { level) }\end{array}$ & Master's degree in educational policy & $\begin{array}{l}\text { Bachelor's degree in social science } \\
\text { and foreign language }\end{array}$ \\
\hline $\begin{array}{l}\text { Grade level } \\
\text { of students }\end{array}$ & Eighth grade & Seventh grade & Seventh grade \\
\hline $\begin{array}{l}\text { Students' reading } \\
\text { proficiency level }\end{array}$ & $\begin{array}{l}\text { "Unsatisfactory" (first- and } \\
\text { second-grade reading levels) }\end{array}$ & $\begin{array}{l}\text { "Partially proficient" (fourth- } \\
\text { or fifth-grade reading levels) }\end{array}$ & $\begin{array}{l}\text { "Proficient" (sixth- or } \\
\text { seventh-grade reading levels) }\end{array}$ \\
\hline
\end{tabular}

The teachers are identified by pseudonyms

times for the classroom visit so that the observations were of their typical practices; instead, they were given a one-week window for the classroom visit. As a nonparticipant observer, the first author wrote field notes while sitting at the back of the classroom, focusing on both the teachers' practices and their interaction with students using previous guidelines (e.g., the Observing Patterns of Adaptive Learning guidelines (OPAL), such as task structure, authority, recognition, evaluation, time; Patrick et al., 1997).

Interviews were conducted with each teacher within a few hours after the classroom observation (between 20 and 40 min $\times 4$ times during the academic year $\times 3$ teachers). During the interviews, the emic views of the teachers' current and previous teaching experiences, their positioning of their students and themselves, and their motivational practices were assessed using semi-structured interview questions that were revised from Turner et al. (2011) (see Appendix A for the interview questions). Contextspecific questions were often included during the interviews (e.g., During class, why did you do ___ and what were you thinking when you did it?; e.g., Calderhead, 1981). The interviews were audio taped and later transcribed. Finally, the teachers' participation in each of the PD sessions and the debriefings after each session with the instructional coach, Ms. Austin, and the two PD facilitators were included for the purpose of triangulation. Importantly, a rapport was developed through interactions with each teacher during the PD sessions, which facilitated classroom observations and interviews.

\subsection{Data analysis}

Case study analysis (Merriam, 1998; Yin, 2014) and coding strategies (Charmaz, 2006; Strauss \& Corbin, 1998) were used to highlight how the teachers' positioning and motivational practices were connected and intertwined. First, open coding was conducted for the collected data with a focus on the language that the teachers used to describe the positioning of their students and themselves, particularly with respect to each other and with critical approaches (Harre \& Moghaddam, 2003; Mitchell, 2013). Example codes for the teachers' positioning of their students (for Mr. Walker) were: "proficient, highest-leveled students, who could do cognitively high-level activities," "absolutely the definition of defiance, continuously talking during class," and "students with faults, who needed to change." Coding was an iterative process (Charmaz,
2006), and similar codes were related and core categories were developed (e.g., "students as problems"). Similarly, example codes for the teachers' practices when motivating and engaging their students, particularly with motivational and with critical approaches (Mitchell, 2013; Reeve, 2009), included the following: "saying 'stop talking," "giving lunch detention," "not talking when students show disrespect," "saying, 'thank you for doing this,"” and "emphasizing responsibility." Similar codes that captured the teachers' practices were again related (e.g., "imposed practices", "reactive, negative, less relational").

Codes and categories related to positioning and motivational practices were compared across each teacher's four interviews and classroom observations, as well as across the three teachers' cases. Then, preliminary relationships among the categories were examined with respect to each teacher, and related categories were compared and combined across the teachers to generate a complete picture of their positioning and motivating practices. The trustworthiness of the data analysis was supported by persistent and multiple observation and triangulation using multiple data sources (e.g., classroom observations, teacher interviews, PD sessions and debriefings after each session with regard to the teachers' reactions) and the peer debriefing during our analysis. The teachers also reviewed and provided feedback about their previous interview summaries during later interviews as a form of informal member-checking.

\section{Findings}

Having differing previous teaching experiences, previous educational experiences, and current roles that served as resources, the three White teachers constructed their identified positioning of their students interactively and reflexively. When they had limited teaching or educational experiences to rely on, they depended on their own narrated histories as students as resources. Across all three White teachers working with emergent bilinguals who were students of color, however, these resources do not appear to have included an understanding about white privilege or the role that race could play in their positioning of themselves or their students. Across all three White teachers, critical discussions about race, diversity, and equity, in terms of motivating and engaging emergent bilinguals, were mostly absent, thus promoting the majoritarian story identified by Mitchell (2013) that there is no story about 
race in the education of secondary emergent bilinguals. Further, the other stories identified by Mitchell (i.e., difference is deficit, meritocracy is appropriate, and English is ALL that matters) were either perpetuated or disrupted by the three teachers, which will be illustrated more thoughtfully below.

Overall, Ms. Daniel positioned her students as individuals, Ms. Austin as monolithic learners, and Mr. Walker as problems. Additionally, the teachers simultaneously positioned themselves in relation to their students. The three White teachers were using different practices in motivating and engaging the socio-culturally and socio-politically positioned emergent bilinguals in the reading-intervention classrooms. The details of these positionings as well as the motivation and engagement efforts enacted by each teacher are described below.

\subsection{Ms. Daniel: students as individuals}

Through her teaching background "as an ESL educator" and a few years of experiences interacting with students from a "similar population," Ms. Daniel positioned her eighth-graders with first- and second-grade reading levels as individuals through understanding their linguistic and cultural histories and backgrounds. Although she reflexively positioned her students as "intentional non-readers, self-proclaimed 'I don't read,' she simultaneously highlighted the importance of thinking critically about who they are for better placement and programming:

...[these] kids are born in the United States; although somebody speaks a language at home other than English, they themselves don't even speak that foreign language ... When you tell them that they are in ESL, they respond with, "What you are talking about? I speak English. Why am I being identified as an English language learner?"

Here Ms. Daniel recognizes that students may be mislabeled and inaccurately sorted into unsuitable programs for their academic development. She also recognizes that students who have Spanish (or another language) in their home may have varying levels of proficiency and engagement with a language other than English. This illustrates her commitment to students as individuals and her understanding of their unique circumstances and linguistic repertoires.

However, at times, Ms. Daniel illustrated deficit perspectives of these unique histories. For instance, later on in the same interaction from the quote directly above, Ms. Daniel said:

\begin{abstract}
... knowing a lot of them aren't literate in their native language ... but maybe they, you know, [in] their early childhood, weren't being read to in their native language ... for example, coming from a low-income home ... they are not quite literate in either language ... that seems to be the case for a quite large population of our students ... .
\end{abstract}

This perspective promoted by the notion of "semi-lingualism" (MacSwan, Rolstadt, \& Glass, 2002) or what Escamilla (2006) illustrates as "bi-illiteracy" or "the socially constructed concept that implies low levels of literacy in both English and Spanish” (p. 2330) is problematic and perpetuates a deficit perspective of students. All students, but emergent bilinguals in particular, have a unique linguistic toolbox that they have constructed for their communicative purposes across their lifetime. This question of literacy in either language that is blamed on the parents or low-income status is something that needs to be disrupted to equitably work with emergent bilinguals (Escamilla, 2006). Positioning students as individuals might be a great start for Ms. Daniel to work well with emergent bilinguals, although she also held the dominant perspectives around students, families, and communities (e.g., difference is deficit, Mitchell, 2013).

Note that Ms. Daniel attempted to understand the complex conditions experienced by her students ("kids mean the best at heart ... and what they are doing on the outside doesn't reflect what's on the inside"). This is notably a contrast to early in her teaching career, when she contrasted her less-motivated and lessengaged students with her own self-identification as a person who was "intrinsically motivated ... motivated by getting As." She earlier felt frustrated seeing students both from her own experiences when young and from her own perspective as a teacher (e.g., controlling; Reeve, 2009); however, through her teaching experiences with this student population and her education in literacy within an urban environment, she started to understand her students as individuals, mostly recognizing their good and beginning to accommodate cultural and linguistic differences. Yet she still had some opportunities for growth in terms of demonstrating the unique aspects of motivation and engagement that are particular to emergent bilinguals and the issues of structural inequities in education (Mitchell, 2013; Rogers, 2014).

She considered motivating her students a "whole other ball game." On the positive side, positioning her students as individuals, Ms. Daniel tried to support students' various psychological needs to motivate and engage students (in contrast to her frustration and yelling during her first few years of teaching). Understanding her students as individuals with their own linguistic and cultural backgrounds, Ms. Daniel reported that she developed her practice as a "hybrid of things," meaning that she created own practices to motivate and engage her students through both the literacy skills curriculum and the bilingual ELD curriculum. For example, in teaching 10 English vocabulary words that the students selected from their reading of Frankenstein, she utilized the students' Spanish language background. She explained similarities between the English words and the translated Spanish words with word structures to help her students learn the words. Ms. Daniel further argued that the curriculum needed to change to become more meaningful and relevant for her "modern" students:
... we still aren't doing things that are very meaningful for students in our school to match what's important in their lives outside of the school ... I love Shakespeare, but he is not the only guy we need to know about in terms of poetry.

By implementing "hybrid of things" that were adapted to her emergent bilingual and by utilizing the students' existing cultural and linguistic resources (Ladson-Billings, 1995), Ms. Daniel aimed to make her practices culturally "relevant," which could support her students' autonomy need (Assor et al., 2002). Ms. Daniel also aimed to "empower a lot of the kids" who often did not experience academic success because of how they and their linguistic abilities were positioned in school, which could support her students' competence need (Deci \& Ryan, 2002). In addition, Ms. Daniel used the "identity project," through which she aimed to prevent students from becoming discouraged when learning presenting skills. She modified her practices to help emergent bilinguals, who did not enjoy talking in front of the class, make presentations about themselves, instead of about content that was disconnected or disinteresting to students. Ms. Daniel perceived that her students trusted her and worked for her. During free time, several students were observed to discuss their future plans for high school applications with her.

However, as much as she had some opportunities for growth in positioning her students, she also seemed to be still in the process 
of embracing her students' cultural and linguistic repertoire:

... I have one student where if I say anything that is remotely strict, even if, just, like, "Can you please stop with the slang," but not in a stern voice, he would put his head down on the table and not work for the rest of the period. He would shut down ... instead, [I] say "thank you for doing this, thank you for doing that." They really respond to it ... So, staying positive is really important.

Her narratives imply that as she came to know her students, she learned to stop being negative to students, to regulate herself, and to remain positive with students. What is not clear is whether she understood the impact of a statement like "Can you please stop with the slang" could have on an emergent bilingual's motivation and engagement. She positions the statement as "not strict," but increasingly teachers are being encouraged to allow students to draw on their entire linguistic repertoire to engage in academic content (Bunch, 2014). Student's language choices, even for emergent bilinguals who may still be developing their linguistic repertoire in English, are often tied to their identity and self-perceptions. When teachers harp on students for speaking in ways that they find comfortable, unnecessary barriers may be added to motivation and engagement.

Overall, by positioning students as individuals, Ms. Daniel was on a path to embrace the emergent bilinguals and the assets they brought to the classroom. She strove to create meaningful learning environments by supporting the emergent bilinguals' needs and drawing on their cultural and linguistic backgrounds. However, Ms. Daniel occasionally subscribed to harmful dominant perspectives regarding students and their families (Mitchell, 2013); thus, she has not yet fully engaged her emerging bilinguals to allow them to construct agentic narratives and to "resist the coercive effects of literacy and language" (Rogers, 2014, p. 248) through critically discussing the issues of sociopolitical power, justice, and equity.

\subsubsection{Ms. Austin: students as monolithic learners}

Aided by her role and experience as an instructional coach, Ms. Austin discussed her responsibility at the school with regard to moving the seventh-graders from the "partially proficient" level (i.e., reading at fifth-grade level) to the "proficient" level. Positioning herself as a person who should support her students' achievement ("My number one reason I am here is achievement, so that's always my bottom line"), Ms. Austin reflexively positioned her students as monolithic learners who, through her attention to data and use of effective strategies, could grow in their learning and show higher achievement. She positioned her students as following:

\begin{abstract}
... the kids who, I think, have been told they are not proficient for so long, they need to see those successes along the way ... [and I think] they have to feel that they can make progress ... I wanted them to know, "Yes, you are partially proficient, but you all can grow this year and that's our job." These kids are, I think, very close to that goal of being "proficient," and I think they want ...
\end{abstract}

Ms. Austin's commitment to the labels of standardized tests such as "partially proficient" and "proficient" as well as her approaches to and discussions around student growth were focused on a dominant cultural narrative that meritocracy is appropriate (Mitchell, 2013) and that student learning can and should progress on a monolithic trajectory towards "proficiency." From this space of engaging in dominant cultural narratives that position students as monolithic and simply needing to work hard, her technicist approaches (Halliday, 1998) to working with students positioned her and her students in particular ways that did not account for their bilingualism or unique cultural and linguistic backgrounds and assets.

In the early part of the academic year, Ms. Austin noted that a few of her "high-needs" students still showed "behavioral issues and attention-seeking behaviors" and at the same time, however, Ms. Austin also identified her current students as more "car[ing] about grades" and "scholarly." Therefore, she decided to seize the opportunity to help her students focus on growth and achievement toward being "proficient." Although Ms. Austin endeavored to recognize that her students were of a different generation ("our kids are growing up in age of technology; TV is on ... all of this noise is going on"), the students' cultural and linguistic backgrounds were not much recognized or acknowledged in her shared view of her students. Coming from ahistorical perspective, Ms. Austin's definition of success and failure for her students, who are emerging bilinguals, was been affected by majoritarian stories (Gillborn, 2005; Mitchell, 2013).

Ms. Austin, who positioned her students by recognizing their abilities to grow and achieve, "really want[ed] them to think with a growth mindset" (Dweck, 200o), and she adopted calibrated practices carefully calculated and planned practices to support students' growth and achievement on state-wide assessments. First, Ms. Austin appreciated the growth-mindset (versus fixed-mindset) concept during a PD, because it was consistent with her view that the students needed to advance to the next level of "proficiency." Ms. Austin frequently recognized and celebrated the students' growth to support their developing competence, through emphasizing both student goal-setting and students' need to track their own progress by graphing their improved assessment scores in a manner that subtracted their previous week's score from their current score:

... Especially with the fluency, they track it [their growth]
every day, and they really get excited by it. "I am moving,
I am moving!" ... "I went up by 14 [points]" ... they have
the same graph for three weeks [for tracking their prog-
ress] ... they like seeing how much they increase, and I
think that keeps them going ... .

However, the value of focusing so intently on fluency in terms of what it offers for reading comprehension is questionable (Goodman, Calfee, \& Goodman, 2013). This technicist approach to reading focuses simply on various components of reading, that may be easily measured, and can provide quick data for students and teachers to monitor. However, what do these scores and the progress students are making illustrate about emergent bilinguals expanding linguistic repertoires and their ability to comprehend text? Very little because fluency focuses on the ability to decode quickly and being able to decode is different from being able to meaningful engage with texts or being able to resist the oppressive effects of literacy and language (Rogers, 2014). Yet, Ms. Austin focused heavily on these kinds of approaches which are supported by mainstream perceptions of reading development, which denotes narrowly defined literacy (Gutiérrez et al., 2009), that have not been illustrated to have a sensitivity to bilingualism or emergent bilinguals (Hopewell \& Escamilla, 2014).

Through the calibrated goal setting and by tracking the students' state-wide assessment scores, Ms. Austin aimed to support the students' competence need (Deci \& Ryan, 2002). In addition, through being very intentional and explicit in providing rationales for the assessments ("what we were doing and why we were doing it"), the students' need for autonomy could have been supported (Reeve, 2009). Moreover, Ms. Austin spent "very intentional" time 
attempting to build a positive community, through "culture-building activities ... risk taking, goal setting, team building, ice breakers ... to build something more positive with them." She was able to build relationships with the students, which she realized were "really key," possibly supporting needs for relatedness (Deci \& Ryan, 2002). She was also positive, relational, and regulating, similar to Ms. Daniel. She frequently used positive comments and recognized the work of individuals in her class (e.g., "Thank you, Jason, for getting started"):

... if I do have to reprimand somebody, things can go negative very quickly, and I think it is up to me to try to get it back. You can feel the cycle, if something happens with [a student name], then, I can switch back to, "Okay, we are moving on, thank you, [another student] for blah blah." The situation will just move on and then kids are motivated ...

In class, students were often observed to follow her exact discourse, saying "Thank you, [other student name]," and they interacted with her both by making eye contact and by raising their hands with questions. Ms. Austin's consistently maintained practices led to academic improvement among her students, about which she expressed pride ("During the October assessment round, the students had made a year's worth of progress with regard to their fluency in just two months"). As the students' scores improved, students' assimilation into the dominant U.S. cultural context could be supported, something Ms. Austin desired.

However, here again, the value of assimilationism is not clear, as the assimilationist ideology "values the preservation of the status quo by newcomers" (Tardy, 2009, p. 281). Yet, we know the long standing status quo for emergent bilinguals is riddled with substantial inequity (Slama, 2014). Assimilationist approaches overlook the unique value and assets that diversity in terms of life experience, identity, interest, language, culture, etc. brings to the classroom. It is possible and desirable for emergent bilinguals to have rich learning experiences in classrooms that affirm their identities and backgrounds as well as expand them for access to meaningful participation in U.S. society. So, while Ms. Austin was proud of her student's growth, she did not recognize the various differences student brought to the learning environment, nor did she build on them. Ms. Austin was still deeply impacted by the dominant cultural narratives about students and schooling (Mitchell, 2013) as is evidenced by how she positioned her students as herself and as monolithic and her work with them as technicist in nature. In the microanalyses of classroom interaction, Ms. Austin indeed adopted various practices to support students' psychological needs. However, without particular attention to the socio, political, and historical context of this work, she in the end was promoting negative majoritarian stories that perpetuate inequity for emergent bilinguals (Mitchell, 2013).

\subsubsection{Mr. Walker: students as problems}

Mr. Walker initially positioned his students as expected to behave like ideal students, whereas later on, they were judged as defiant students with deficits. Essentially, Mr. Walker positioned his students as problems. Early in the academic year, Mr. Walker's initially expected his seventh-grade students, who had been sorted into his class based on their assessed reading level of "proficiency," to be an ideal student. According to Ms. Austin, Mr. Walker's initial expectation for his students was a little "unrealistic" (shared during a PD debriefing). Mr. Walker reflexively positioned his students as "perfect angels" and "dedicated" individuals, once he interpreted that these students met his expectations by being nice, saying hello, being respectful, doing everything that they were supposed to do, and paying attention. However, when his students' behaviors did not meet his expectations because of their "idle chattering," his frustration caused him to position these students as "eager to fail."

As a first-year teacher with limited previous teaching experience to rely on (e.g., little teacher training, pedagogy knowledge, content knowledge), Mr. Walker's own history as a student was served as his ideal student image. During the second interview, he contrasted himself to his "disrespectful" students:
... when I was in school, if a teacher asked me to stop talking twice ... that was it ... I would never argue with a teacher. I would never do what some of these kids do to me ... You respect your teacher 'cause he's your teacher ... It wasn't the teacher's fault ... the kid's behavior was ... that student's fault. That student needed to change ...

Mr. Walker's ideal student image further contrasted with his views on his students (e.g., "absolutely the definition of defiance") as the academic year progressed as the students' low engagement became more frequent. Eventually, Mr. Walker constructed deficient views of his students by perceiving them as unable to show respect and to behave ("I think discipline in their homes is like ... they can yell at their parents") informed by negative dominant cultural narratives (Mitchell, 2013). He ended up viewing some of the students as not "at the level where they can really synthesize, evaluate, and analyze" what they were asked to do. He positioned himself against his students as "an angry mean old man" and "a nerd."

Given Mr. Walker's expectation that his students were the ideal students, his motivational practices focused on imposing his vision and goal. Having "big visions and goals" for his students and himself early in the academic year, he eagerly "challenged" his students by implementing a research project unit that he created. The example topics for the research were global warming, a presidential debate, or the Chicago teacher strike:

This unit is special for me 'cause for the first time, I cre-
ated the unit and I spent a lot of time on it ... that was chal-
lenging and rigorous but also is hopefully going to engage
them...My vision is to have a nice three days of presenta-
tions, and the kids are really excited, and we're celebrat-
ing and I would love to invite administrators to watch.

However, the students did not meet his expectations. Mr. Walker felt that his visions of being productive and working hard seemed to be "not ingrained in them at all yet." Not being able to see students' views, he used increasingly louder voices in class and tried to provide "really strong expectations ... by implement[ing] stronger techniques" to impose his ideas (i.e., controlling method; Reeve, 2009), with very few indications that he supported students' autonomy needs (Deci \& Ryan, 2002). For example, he stressed responsibility: "You can't go into your job when you are 20 years old and say, 'I don't want to do this work' ... In a way, school is your job right now "cause you are 12 years old."

Furthermore, unlike Ms. Daniel and Ms. Austin, Mr. Walker engaged in reactive and negative motivational practices. When students at times showed excitement and jumped in while the teacher was talking, Mr. Walker perceived them as disruptive and disrespectful contrasting them with his unrealistic ideal image of students. Becoming frustrated and upset, he engaged in punitive and negative statements (e.g., "Quiet!"; "I am excited that you guys know the news, but I need you to not call out"; "Why are you talking while I am talking?"). The reactive and negative practices resulted in feelings of disconnection for both the teacher and the students (Deci \& Ryan, 2002). Mr. Walker thought it was difficult 
to be positive and relational:

I don't do enough positive things, like, “Oh, thank you for doing this" ... How can I thank anyone in this class when all I want to do is just tell everyone to stop talking? [compared to when he was young] Now ... teachers have to really work hard to make sure they have relationships with students and the students feel respected ... [but] I can't spend half of a year getting this relationship of respect with students.

At the end of the academic year, Mr. Walker reported that he realized the importance of being positive and of building relationships both from the other teachers and from the PDs, but he still maintained his original identification of the students without fully establishing the new practices. Furthermore, Mr. Walker became more frustrated and frequently argued with individual students as the academic year progressed, and the students talked back more actively repositioning themselves against the teacher's positioning (Tan \& Moghaddam, 1999). Several students continuously responded to him with the following: "I don't care that you called my dad. I am just mad at you" or "I am in trouble because you are mean." In the end, Mr. Walker positioned the students as problems without recognizing his own limitations in terms of his expertise as a teacher nor his biases and perceptions informed by dominant cultural narratives (Mitchell, 2013).

\section{Discussion and implication}

Essentially, in this study we found three teachers positioning themselves and students in different ways to varying effects. We argue that in accordance with Mitchell (2013), "Educators and educational researchers may participate in the perpetuation of structural inequities by researching and teaching from uncritical standpoints in which deficit perspectives are passed on and insufficient forms of education are embraced" (p. 341). Therefore, we suggest that motivation and engagement work for emergent bilinguals must meaningfully include attention to critical perspectives and strive to disrupt negative dominant discourses that oppress emergent bilingual students and other students of color. We explore this further below.

\subsection{Motivating and engaging the positioned emergent bilinguals}

This study found several themes with regard to teachers working with emergent bilinguals in the context of reading-intervention classes. First, aligned with the previous literature on achievement motivation, teachers' use of adaptive motivational practices, such as the support of psychological needs (e.g., relatedness, competence, and autonomy needs: Deci \& Ryan, 2002), appeared to connect to higher observed engagement of emergent bilinguals. Both Ms. Daniel and Ms. Austin intentionally emphasized being positive and building relationships with their students, which seemed to contribute to the support of teachers and students' relatedness needs. The finding aligns with Suárez-Orozco, Pimentel, and Martin (2009), who have argued that school-based tangible and emotionally supportive relationships led to immigrant youth exerting greater efforts in their new linguistic and cultural context of schoolwork. Yet, both Ms. Daniel and Ms. Austin could still improve their support of student psychological needs through enhanced attention to the sociopolitical context of language, race, culture, etc. in schooling and society (Mitchell, 2013). Particularly Ms. Austin could grow in her engagement with students as having rich and varied histories and interests rather than as monolithic learners who should all assimilate.
Importantly, the teachers' motivational practices to support emergent bilinguals' competence and autonomy needs varied to the same extent as their positioning of students. In supporting emergent bilinguals' competence needs, adopting an incremental perspective of intelligence (Dweck, 200o), Ms. Austin used carefully and intentionally calibrated goal setting and by tracking and celebrating the students' improved fluency and state-wide assessment scores. However, based on narrowly defined literacy (Gutiérrez et al., 2009), her practices were not sensitive to their bilingualism, and aimed to support students' successful assimilation into the dominant U.S. cultural context, a goal that is questionable from a perspective of equity and diversity (Viesca, 2013). In comparison, for Ms. Daniel, improved scores on the state reading assessment were less of a focus. By developing a deeper understanding of possible reasons for emergent bilinguals' low motivation and their political context, Ms. Daniel began to advocate her students' bilingual and bicultural backgrounds. Her use of hybrid practices supported student competence needs by drawing on students' existing strengths and encouraging them to use their existing linguistic and cultural funds of knowledge (Mercado \& Moll, 1997).

Similarly, with respect to supporting students' autonomy needs, Ms. Austin's autonomy-supportive practices involved not only providing clear rationales for various assessments and academic tasks but also intentionally explaining the relevance of school tasks to students' advancement to a higher proficiency level (Assor et al., 2002; Reeve, 2009). Yet, here again, Ms. Austin did this in the context of meritocractic subscription to the labels and positioning of students in the curriculum and assessment programs without accounting for student diversity as an asset. In comparison, Ms. Daniel's autonomy-supportive practices involved linguistical and cultural "relevance" (e.g., Assor et al., 2002) to the students' backgrounds. She brought the curriculum to the students through modification and hybridization, a strategy that differed from Ms. Austin's practices. Note that Ms. Daniel occasionally subscribed to harmful dominant perspectives (Mitchell, 2013), and, thus, has not yet fully engaged her students to construct agentic narratives and to "resist the coercive effects of literacy and language" (Rogers, 2014, p. 248). However, she was on a path to supported students' cultural, social, and academic needs through cultural relevance (Ladson-Billings, 1995) and adopt multiculturalism (versus monoculturalism), like Mrs. Young in Yoon's (2008) study.

Although Mr. Walker aimed to motivate emergent bilinguals through what he considered to be rigorous and challenging lessons, he did so by imposing his own vision and goals for students instead of emphasizing students' interest and relevance (lack of support for the students' autonomy needs). He ended up blaming their deficits (lack of support for the students' competence needs), adopting imposed motivational practices on students who were perceived as deficits and disrespectful (i.e., controlling practices; Reeve, 2009). For Mr. Walker, students were the problem.

\subsection{Teacher positioning and adaptive motivating practices}

Although the teachers were aware of various strategies from their monthly PD sessions, the White teachers all differed in their motivational practices, aligned with their negotiated identities of their students, who were primarily emergent bilinguals and students of color. With respect to the different positioning of emergent bilinguals adopted by the White teachers, a notable pattern was found. When the teachers (e.g., Mr. Walker, and Ms. Daniel in her early teaching career) had just begun teaching and had only limited teaching and educational experiences upon which to rely, they negotiated their students' positioning by relying on the teachers' own narrated histories of themselves as students utilizing dominant 
cultural narratives. Their identity positioning of their students was shaped by their comparisons of their students with their younger selves who were intrinsically motivated, obedient, and engaged in the dominant U.S. cultural context as the "norm." Having inadequate opportunities to understand their historical, cultural, racialized, and political contexts, as well as possibly limited pedagogical knowledge and content knowledge, Mr. Walker and Ms. Daniel (in her early teaching career) judged students as deficient and disrespectful and yelled at the students (i.e., controlling practices; Reeve, 2009) with emotional burnout. Pelletier, Seguin-Levesque, and Legault (2002) or Reeve (2009) similarly reported that teachers tend to become controlling with students when they believe that their student are less motivated.

However, in her current year of teaching, Ms. Daniel drew upon several years of experiences getting to know her student population (at previous urban schools) and opportunities to investigate who the students are and their contexts (through her advanced degrees in language and literacy). These opportunities allowed Ms. Daniel to re-position her students as an individual with linguistic and cultural histories and backgrounds. She became supportive of students' psychological needs, and she was on a path to draw upon their cultural resources that were undervalued in U.S. society and aimed to modify the existing curriculum. This study further articulates that by learning more about who the students are, where the students are from, and how they are situated culturally, linguistically, racially, and politically, i.e., by engaging in a shifted positioning teachers could better support the students' psychological, social, and cultural needs.

One important implication of this investigation is that teachers should be aware of their positioning of their students in the cultural, linguistic, racial, and political context of language and literacy classrooms (e.g., Kumaravadivelu, 2012; Mitchell, 2013). School leaders and teacher educators could encourage current and future teachers to reflect on their positioning processes (e.g., based on asset versus deficit perspectives, or based on monolingual versus multilingual perspectives) as associated with their motivational practices in the classroom. A holistic approach of teacher education could support the teachers' deeper understanding of students with varying linguistic, racial, and cultural backgrounds, moving away from a technicist, skills-based teacher preparation (e.g., Jurow, Tracy, Hotchkiss, \& Kirshner, 2012; Reeves, 2009). For example, autonomy support for emergent bilinguals would not simply be a matter of learning and enacting strategies (e.g., providing rationales for high-stakes testing), but instead would be more aligned with the degree to which teachers understand their own as well as their students' cultural, linguistic, racial, and political contexts.

\subsection{Conclusion and limitations}

This study contributes to the field by offering deeper insight into how the participating teachers' motivational practices were enacted through their views of emergent bilinguals, which were aided by resources from the teachers' experiences and by their current roles. This study has implications for teacher and teacher educators in a larger international context, which features issues of immigration and emergent bilinguals. Despite these contributions, this study's limitations include the inability to conduct prolonged interviews and to collect additional observational data outside of the classroom context, which would have improved the researchers' ability to discern changes in the teachers' identities. Another limitation was the lack of opportunity to interview students, who could have provided insightful data. All of the teachers were from one school in one region of the country, and future studies could examine teachers from different social, cultural, racial, linguistic, and political backgrounds with regard to their positioning and practices. Future investigation could also involve how teachers' critical reflection of themselves and a further understanding of their student population could shape their practices to be more adaptive.

Acknowledgments - This project was funded by the Faculty Development Grant Program, Center for Faculty Development, University of Colorado Denver.

\section{Appendix A}

\section{Questions Based on the Classroom Observation.}

1. What were your goals in your class today? Can you describe what you did during class today?

2. Why did you decide to do __ertain activity, such as grouping, certain instruction, timing, asking questions ... based on the classroom observation)?

3. What were you thinking and feeling when you were doing (or during the class)?

\section{General Questions.}

4. How did you see yourself as a teacher in the class today? What was your role?

5. How would you describe your students in this class? (across class?)

6. How do you motivate your students in general in this class? (across class?)

7. When do you find it hard to motivate students (individual students or groups of students)? Could you describe this difficulty?

\section{Questions from Turner et al. (2011).}

8. What do you think motivated students to try hard in your class? 9. What reduced motivation in your class?

10. What sorts of things do you do to try to motivate your students?

11. How have your ideas about what motivates students changed over the years that you have been a teacher, if at all?

12. How have your ideas about what motivates students changed over the semester, if at all? a. What do you see as a role of PD on your teaching? (Please be honest.) Any strategies adopted?

13. How much influence do you think you have on students' motivation in your class?

14. If you could change anything about the school system (e.g., the length of the school day, number of students in the classroom, curriculum you use, etc.) to enhance student motivation, what would you change?

\section{References}

Assor, A., Kaplan, H., \& Roth, G. (2002). Choice is good, but relevance is excellent: autonomy-enhancing and suppressing teacher behaviours in predicting student's engagement in school work. British Journal of Educational Psychology, 72, 261-278.

Bunch, G. C. (2013). Pedagogical language knowledge preparing mainstream teachers for English learners in the new standards era. Review of Research in Education, 37(1), 298-341. http://dx.doi.org/10.3102/o091732X12461772

Bunch, G. C. (2014). The language of ideas and the language of display: reconceptualizing "academic language" in linguistically diverse classrooms. International Multilingual Research Journal, 8(1), 70-86. http://dx.doi. org/10.1080/ 19313152.2014.852431.

Calderhead, J. (1981). Stimulated recall: a method for research on teaching. British Journal of Educational Psychology, 51(2), 211-217.

Charmaz, K. (2006). Constructing grounded theory: A practical guide through qualitative analysis. London: Sage.

Deci, E. L., \& Ryan, R. M. (Eds.). (2002). Handbook of self-determination research. Rochester, NY: University of Rochester Press. 
Denton, C. A., Fletcher, J. M., Anthony, J. L., \& Francis, D. J. (2006). An evaluation of intensive intervention for students with persistent reading difficulties. Journal of Learning Disabilities, 39, 447-466.

Dweck, C. S. (200o). Self-theories: Their role in motivation, personality and development. Philadelphia, PA: Taylor \& Francis.

Edmonds, M. S., Vaughn, S., Wexler, J., Reutebuch, C., Cable, A., Klingler-Tackett, K., et al. (2009). A synthesis of reading interventions and effects on reading comprehension outcomes for older struggling readers. Review of Educational Research, 79, 262-300.

Escamilla, K. (2006). Semilingualism applied to the literacy behaviors of Spanish-speaking emerging bilinguals: bi-illiteracy or emerging biliteracy? Teachers College Record, 108(11), 2329-2353.

García, O. (2009). Emergent bilinguals and TESOL: what's in a name? TESOL Quarterly, 43, 322-326.

García, O., \& Wei, L. (2014). Translanguaging: Language, bilingualism and education. Basingstoke, England: Palgrave Macmillan.

Gillborn, D. (2005). Education policy as an act of white supremacy: whiteness, critical race theory and education reform. Journal of Education Policy, $20(4), 485-505$.

Goodman, K. S., Calfee, R. C., \& Goodman, Y. M. (Eds.). (2013). Whose knowledge counts in government literacy policies? Why expertise matters. New York, NY: Routledge.

Gutiérrez, K. D., Morales, P. Z., \& Martinez, D. C. (2009). Re-mediating literacy: culture, difference, and learning for students from nondominant communities. Review of Research in Education, 33, 213-245.

Halliday, J. (1998). Technicism, reflective practice and authenticity in teacher education. Teaching and Teacher Education, 14(6), 597-605.

Harper, C. A., \& de Jong, E. J. (2009). English language teacher expertise: the elephant in the room. Language and Education, 23(2), 127-151.

Harre, R., \& Moghaddam, F. (2003). The self and others: Positioning individuals and groups in personal, political, and cultural contexts. Westport, CT: Praeger.

Harre, R., \& van Langenhove, L. (1999). Positioning theory. Malden, MA: Blackwell.

Hopewell, S., \& Escamilla, K. (2014). Struggling reader or emerging biliterate student? Reevaluating the criteria for labeling emerging bilingual students as low achieving. Journal of Literacy Research, 46(1), 68-89. http://dx.doi. org/10.1177/ 1086296X13504869

Jurow, A. S., Tracy, R., Hotchkiss, J., \& Kirshner, B. (2012). Designing for the future: how the learning sciences can inform the trajectories of preservice teachers. Journal of Teacher Education, 63(2), 147-160.

Kamil, M. L., Borman, G. D., Dole, J., Krai, C., Salinger, T., \& Torgesen, J. (2008). Improving adolescent literacy: Effective classroom and intervention practices: A practice guide (NCEE 2008-4027). Washington, DC: National Center for Education Evaluation and Regional Assistance, Institute of Education Sciences, U.S. Department of Education. Retrieved from http://files. eric.ed.gov/fulltext/ ED502398.pdf

Kaplan, A., Katz, I., \& Flum, H. (2012). Motivation theory in educational practice: knowledge claims, challenges, and future directions. In K. R. Harris, S. G. Graham, \& T. Urdan (Eds.), APA educational psychology handbook Vol. 2: Individual differences, cultural considerations, and contextual factors in educational psychology (pp. 165-194). Washington, DC: American Psychological Association.

Kumaravadivelu, B. (2012). Language teacher education for a global society: A modular model for knowing, analyzing, recognizing, doing, and seeing. New York: Routledge.

Ladson-Billings, G. (1995). Toward a theory of culturally relevant pedagogy. American Educational Research Journal, 32, 465-491.

Love, B. J. (2004). Brown plus 50 counter-storytelling: a critical race theory analysis of the "majoritarian achievement gap" story. Equity and Excellence in Education, 37(3), 227-246.

Lucas, T., \& Villegas, A. M. (2011). A framework for preparing linguistically responsive teachers. In T. Lucas (Ed.), Teacher preparation for linguistically diverse classrooms: A resource for teacher educators (pp. 55-72). New York, NY: Routledge.

MacSwan, J., Rolstad, K., \& Glass, G. (2002). Do some school-age children have no language? Some problems of construct validity in the pre-LAS Español. Bilingual Research Journal, 26, 395-420.

Mercado, C., \& Moll, L. C. (1997). The study of funds of knowledge: collaborative research in Latino homes. Centro, 9(9), 26-42.

Merriam, S. B. (1998). Qualitative research and case study applications in education: Revised and expanded from case study research in education. San Francisco: Jossey-Bass.

Mitchell, K. (2013). Race, difference, meritocracy, and English: majoritarian stories in the education of secondary multilingual learners. Race Ethnicity and
Education, 16(3), 339-364

Moore, B., \& Klingner, J. K. (2014). Considering the needs of English language learner populations: an examination of the population validity of read ing intervention research. Journal of Learning Disabilities, 47(5), 391-408.

National Assessment of Educational Progress. (2013). The Nation's report card. Washington, DC: U.S. Department of Education. National Center for Education Statistics. Retrieved from http://nces.ed.gov/nationsreportcard.

Nolen, S. B., Ward, C. J., \& Horn, I. S. (2014). Changing practice(s): a situated account of teachers' motivations to learn. In P. W. Richardson, S. Karabenick, \& H. Watt (Eds.), Teacher motivation: Theory and practice. NY: Routledge.

Olsen, B. (2008). How reasons for entry into the profession illuminate teacher identity development. Teacher Education Quarterly, 35(3), 3-6.

Patrick, H., Ryan, A. M., Anderman, L. H., Middleton, M., Linnenbrink, L., Hruda, L. Z., et al. (1997). OPAL. Observing patterns of adaptive learning: A protocol for classroom observations. Ann Arbor: University of Michigan.

Pelletier, L. G., Seguin-Levesque, C., \& Legault, L. (2002). Pressure from above and pressure from below as determinants of teachers' motivation and teaching behaviors. Journal of Educational Psychology, 94, 186-196.

Pintrich, P. R., \& Schunk, D. H. (2002). Motivation in education: Theory, research, and applications (2nd ed.). Upper Saddle River, NJ: Prentice.

Quate, S., \& McDermott, J. (2009). Clock watchers: Six steps to motivating and engaging disengaged students across content areas. Portsmouth, $\mathrm{NH}$ : Heinemann

Reeve, J. (2009). Why teachers adopt a controlling motivating style toward students and how they can become more autonomy supportive. Educational Psychologist, 44(3), 159-175.

Reeves, J. (2009). Teacher investment in learner identity. Teaching and Teacher Education, 25, 34-41.

Rodriguez, T. L. (2011). Stories of self, stories of practice: enacting a vision of socially just pedagogy for Latino youth. Teaching Education, 22(3), 239-254.

Rogers, R. (2004). Storied selves: a critical discourse analysis of adult learners' literate lives. Reading Research Quarterly, 39(3), 272-305.

Rogers, R. (2014). Coaching literacy teachers as they design critical literacy practices. Reading \& Writing Quarterly, 30(3), 241-261.

Slama, R. B. (2014). Investigating whether and when English learners are reclassified into mainstream classrooms in the United States: a discrete-time survival analysis. American Educational Research Journal, 51(2), 220-252.

Strauss, A., \& Corbin, J. (1998). Basics of qualitative research: Techniques and procedures for developing grounded theory (2nd ed.). Thousand Oaks, CA: Sage.

Suárez-Orozco, C., Pimentel, A., \& Martin, M. (2009). The significance of relationships: academic engagement and achievement among newcomer immigrant youth. Teachers College Record, 111(3), 712-749.

Tan, S., \& Moghaddam, F. M. (1999). Positioning in intergroup relations. In R. Harré, \& L. van Langenhove (Eds.), Positioning theory (pp. 178-194). Oxford, UK: Blackwell.

Tardy, C. M. (2009). 'Press 1 for English': textual and ideological networks in a newspaper debate on US language policy. Discourse Society, 20(2), 265-286.

Tharp, R. G., Estrada, P., Stoll Dalton, S., \& Yamauchi, L. A. (200o). Teaching transformed: Achieving excellence, fairness, inclusion, and harmony. Boulder, CO: Westview Press.

Turkan, S., de Oliveira, L. S., Lee, O., \& Phelps, G. (2014). Proposing a knowledge base for teaching academic content to English language learners: Disciplinary linguistic knowledge. Teachers College Record, 116(3).

Turner, J. C., Warzon, K. B., \& Christensen, A. (2011). “They have no motivation": changes in teachers' practices and beliefs during a nine-month collaboration on motivation in mathematics. American Educational Research Journal, 48, 718-762.

Urdan, T. (2014). Concluding commentary: understanding teacher motivation: what is known and what more there is to learn. In P. W. Richardson, S Karabenick, \& H. Watt (Eds.), Teacher motivation: Theory and practice. NY: Routledge.

Viesca, K. M. (2013). Linguicism and racism in Massachusetts education policy. Education Policy Analysis Archives, 21(52).

Wilcox, K. A., Murakami-Ramalho, E., \& Urick, A. (2013). Just-in-time pedagogy: teachers' perspectives on the response to intervention framework. Journal of Research in Reading, 36(1), 75-95.

Yeager, D. S., \& Dweck, C. S. (2012). Mindsets that promote resilience: when students believe that personal characteristics can be developed. Educational Psychologist, 47, 302-314.

Yin, R. K. (2014). Case study research: Design and methods (5th ed.). Thousand Oaks, CA: Sage Publications Inc.

Yoon, B. (2008). Uninvited guests: the influence of teachers' roles and pedagogies on the positioning of English language learners in the regular classroom. American Educational Research Journal, 45, 495-522. 